\section{TINJAUAN HUKUM TERKAIT PENCEMARAN LIMBAH RUMAH TANGGA MENURUT UNDANG-UNDANG NOMOR 32 TAHUN 2009 TENTANG PERLINDUNGAN DAN PENGELOLAAN LINGKUNGAN HIDUP ${ }^{1}$ Oleh: Veren Veronika Pontoh ${ }^{2}$}

Denny B. A. Karwur ${ }^{3}$

Fonnyke Pongkorung ${ }^{4}$

\section{ABSTRAK}

Tujuan dilakukannya penelitian ini adalah untuk mentgetahui bagaimana dampak yang ditimbulkan oleh limbah rumah tangga terhadap lingkungan hidup dan apakah pencemaran lingkungan hidup oleh limbah rumah tangga sebagai suatu tindak pidana serta bagaimana sanksi terhadap pelaku pencemaran limbah rumah tangga menurut UU No. 32 Tahun 2009 tentang Perlindungan dan Pengelolaan Lingkungan Hidup. Dengan menggunakan metode penelitian yuridis normatif, disimpulkan: 1 . Limbah rumah tangga dapat mengganggu kesehatan manusia dan kelangsungan hidup makhluk hidup lainnya. Menumpuknya limbah rumah tangga mengandung bakteri dan sangat membahayakan kesehatan lingkungan. Dampak dari limbah rumah tangga sangatlah mengganggu lingkungan hidup karena mengancam kehidupan ekosistem air, menyebabkan penyakit, menurunnya kualitas air, tumbuhnya kuman penyakit, membuat air tak layak untuk di konsumsi dan menyebabkan banjir. 2. Pencemaran lingkungan oleh limbah rumah tangga telah memenuhi kriteria sebagai suatu tindak pidana, karena limbah rumah tangga yang merupakan sisa hasil kegiatan rumah tangga baik itu berbentuk cair maupun padat sudah melampaui ambang batas baku mutu yang disyaratkan dan merusak atau mencemarkan lingkungan hidup. 3. Sanksi bagi pelaku pencemaran limbah rumah tangga menurut UU No. 32 Tahun 2009 adalah dikenakan pidana penjara paling singkat 1 (satu) tahun dan paling lama 15 (lima belas) tahun dan denda paling sedikit Rp. 1.000.000.000,00 (satu miliar rupiah) dan paling

\footnotetext{
${ }^{1}$ Artikel Skripsi.

2 Mahasiswa pada Fakultas Hukum Unsrat, NIM : 16071101400

${ }^{3}$ Fakultas Hukum Unsrat, Doktor IImu Hukum

${ }^{4}$ Fakultas Hukum Unsrat, Magister IImu Hukum
}

banyak Rp. 15.000.000.000,00 (lima belas miliar rupiah) sebagaimana tercantum dalam Pasal 98, 99, 100, 102 dan 103. Terdapat akumulasi pidana pokok yaitu pidana penjara dan pidana denda.

Kata kunci: Tinjauan Hukum, Pencemaran, Limbah Rumah Tangga, Perlindungan dan Pengelolaan Lingkungan Hidup.

\section{PENDAHULUAN}

\section{A. Latar Belakang}

Kurangnya kesadaran terhadap lingkungan sendiri. Masih banyak yang masih kurang mengerti akan kebersihan lingkungan, sehingga mereka dengan mudahnya membuang limbah yang sangat berbahaya bagi lingkungan. Seperti halnya aktivitas sehari-hari yang kita lakukan seperti mandi, mencuci dan berbagai aktivitas lain yang kita anggap sepele namun menghasilkan sisa buangan yang dapat membahayakan manusia dan lingkungan khususnya lingkungan laut. Dari sekian banyak aktifitas manusia yang paling berbahaya adalah limbah rumah tangga.

Rumah tangga banyak menghasilkan limbah. Pasal 1 angka 20 UU No. 32 Tahun 2009 tentang Perlindungan dan Pengelolaan Lingkungan Hidup menyebutkan bahwa Limbah adalah 'sisa suatu usaha dan/atau kegiatan'. ${ }^{5}$

Pertumbuhan jumlah penduduk yang semakin pesat dan diiringi dengan semakin merebaknya permukiman akan sangat berpengaruh terhadap jumlah buangan limbah yang ditimbulkan oleh aktivitas dalam rumah tangga. Buangan limbah cair yang bersumber dari rumah tangga jika tidak dikelola dengan baik dapat memberikan dampak negatif pada lingkungan. Komponen pencemaran air akan menentukan terjadinya indikator pencemaran air. Pembuangan limbah rumah tangga dan kegiatan masyarakat lainnya jika tidak memperhatikan kelestarian lingkungan dapat berpotensi terhadap terjadinya pencemaran lingkungan air.

Kehadiran sampah merupakan salah satu persoalan yang dihadapi oleh masyarakat. Keberadaan sampah tidak diinginkan bila dihubungkan dengan faktor kebersihan, kesehatan, kenyamanan dan keindahan (estetika). Tumpukan sampah yang

\footnotetext{
${ }^{5}$ UU No. 32 Tahun 2009 Tentang Perlindungan Dan Pengelolaan Lingkungan Hidup
} 
mengganggu kesehatan dan keindahan lingkungan merupakan jenis pencemaran yang dapat digolongkan dalam degradasi lingkungan yang bersifat sosial. ${ }^{6}$ Masalah pembuangan dan pengelolaan sampah merupakan salah satu faktor yang mempengaruhi lingkungan. Sampah adalah bahan buangan sebagai aktivitas manusia yang merupakan bahan yang sudah tidak dapat dipergunakan lagi. Peraturan Pemerintah Nomor 81 Tahun 2012 menyebutkan bahwa 'sampah rumah tangga adalah sampah yang berasal dari kegiatan sehari-hari dalam rumah tangga yang tidak termasuk tinja dan sampah spesifik'.

\section{B. Rumusan Masalah}

1. Bagaimana dampak yang ditimbulkan oleh limbah rumah tangga terhadap lingkungan hidup?

2. Apakah pencemaran lingkungan hidup oleh limbah rumah tangga sebagai suatu tindak pidana?

3. Bagaimana sanksi terhadap pelaku pencemaran limbah rumah tangga menurut UU No. 32 Tahun 2009 tentang Perlindungan dan Pengelolaan Lingkungan Hidup?

\section{Metode Penelitian}

Jenis penelitian ini adalah penelitian deskriptif. Adapun metode pendekatan yang digunakan adalah yuridis normatif, artinya pembahasan terhadap masalah yang ada, peneliti akan melihat pada ketentuan peraturan perundang-undangan yang ada kaitannya dengan UU No. 32 Tahun 2009 tentang Perlindungan dan Pengelolaan Lingkungan Hidup dan peraturan perundangan lainnya yang terkait.

\section{PEMBAHASAN}

\section{A. Dampak Dari Pencemaran Limbah Rumah Tangga Terhadap Lingkungan Hidup}

Limbah rumah tangga setiap hari diproduksi oleh rumah tangga-rumah tangga yang ada di dunia ini, demikian juga dengan kita yang hidup di negara kita Indonesia. Limbah rumah tangga sangatlah merusak lingkungan hidup, bahkan sudah memasuki ambang yang mengkhawatirkan. Dari sekian banyak aktivitas

\footnotetext{
${ }^{6}$ Ibid.
}

manusia, ternyata yang yang paling berbahaya adalah limbah rumah tangga, bahkan aktivitas sehari-hari yang kita lakukan seperti mandi, mencuci dan berbagai aktivitas lain yang kita anggap sepele namun menghasilkan sisa buangan ternyata dapat membahayakan bagi manusia dan lingkungan.

Sampah merupakan salah satu contoh limbah rumah tangga, dimana sampah ini ada 2 (dua) jenis yaitu sampah organik dan sampah anorganik. Sampah rumah tangga sebagian besar merupakan atau tergolong sebagai sampah organik yaitu sampah potonganpotongan sayur dan bahan-bahan masakan atau daun-daun yang berjatuhan di kebun, dan halaman, sedangkan plastik, kaleng, baterei, potongan logam dan kertas merupakan sampah anorganik yang tidak dapat terurai atau membusuk secara alamiah, walaupun bisa terurai akan sangat membutuhkan waktu puluhan tahun. $^{7}$

Limbah rumah tangga dapat mengganggu kesehatan manusia dan kelangsungan hidup makhluk hidup lainnya. Menumpuknya limbah rumah tangga mengandung bakteri dan sangat membahayakan kesehatan lingkungan. Dampak dari limbah rumah tangga sangatlah mengganggu lingkungan hidup karena:

1. mengancam kehidupan ekosistem air

2. menyebabkan penyakit

3. menurunnya kualitas air

4. tumbuhnya kuman penyakit

5. membuat air tak layak untuk di konsumsi

6. menyebabkan banjir

Limbah domestik dapat berdampak terjadinya pencemaran tanah yang berasal atau merupakan timbunan sampah dimana limbah ini sangat mengganggu karena lindi (air sampah), bau dan estetika. Timbunan sampah juga menutupi permukaan tanah sehingga tanah tidak bisa dimanfaatkan lagi. Timbunan sampah bisa menghasikan gas nitrogen dan asam sulfida, adanya zat mercury, chrom dan arsen pada timbunan sampah bisa timbulkan pencemaran tanah/gangguan terhadap bio tanah, tumbuhan, merusak struktur permukaan tanah. ${ }^{8}$ Limbah cair seperti tinja, deterjen, oli bekas, cat yang juga merupakan limbah rumah

\footnotetext{
${ }^{7}$ Titi Chahar Khan, Dampak Limbah Rumah Tangga dan Penanggulangannya, diakses dari tiyfaoji.blogspot.com pada tanggal 1 April 2020.

${ }^{8}$ H.M Hadin Muhjad, Op-Cit, hlm. 91.
} 
tangga, peresapannya ke dalam tanah akan merusak kandungan air tanah dan zat kimia yang terkandung didalamnya dapat membunuh mikro-organisme di dalam tanah. Limbah domestik yang bisa menyebabkan pencemaran tanah bisa berasal dari daerah pemukiman penduduk, perdagangan/pasar/tempat usaha hotel dan lain-lain; kelembagaan misalnya kantor-kantor pemerintahan dan swasta dan wisata yang bisa berupa limbah padat dan cair. Limbah padat berbentuk sampah anorganik yang tidak bisa diuraikan oleh mikro-organisme misalnya kantong plastik, bekas kaleng minuman, bekas botol plastik air mineral dan sebagainya. Sedangkan limbah cair berbentuk tinja, detergen, oli, cat jika meresap ke dalam tanah akan merusak kandungan air tanah dan bisa membunuh mikro-organisme di dalam tanah. ${ }^{9}$

Limbah rumah tangga dapat mempengaruhi kualitas air sehingga menyebabkan terjadinya pencemaran, misalkan air mandi dan air cucian. Limbah rumah tangga yang masuk ke dalam lingkungan laut mempunyai dampak negatif sebagai berikut: ${ }^{10}$

1. Eutrofikasi, penyebab terbesar adalah sungai yang bermuara di laut, limbah yang terbawa salah satu bahan kimia yang digunakan sebagai pupuk alam pertanian maupun limbah dari peternakan dan manusia, salah satu yang paling sering ditemukan adalah detergen. Eutrofikasi adalah perairan menjadi terlalu subur sehingga terjadi ledakan jumlah alga dan fitoplankton yang saling berebut mendapat cahaya untuk fotosintesis. Karena terlalu banyak maka alga dan fitoplankton di bagian bawah akan mengalami kematian secara masal, serta terjadi kompetensi dalam mebgkonsumsi $\mathrm{O} 2$ karena terlalu banyak organisme pada tempat tersebt. Sisa respirasi mengahsilkan banyak $\mathrm{CO} 2$ sehingga kondisi perairan menjadi anoxic dan menyebabkan kematian massal pada hewan-hewn di perairan tersebut.

2. Peningkatan emisi CO2 akibat dari banyaknya kendaraan, penggunaan listrik berlebihan serta buangan industri akan memberikan efek peningkatan kadara keasaman laut. Peningkatan $\mathrm{CO} 2$ tentu akan berakibat buruk manusia terkait denan kesehatan pernapasan. Salah satu fungsi laut adalah sebagai penyerap dan penetral CO2 terbesar di bumi. Saat $\mathrm{CO} 2$ di atmosfer meningkat maka laut juga akan menyerap lebih banyak CO2 yang akan mengakibatkan meningkatnya derajat keasaman laut.

3. Plastik, yang menjadi masalah terbesar dan paling berbahaya, banyak hewan yang hidup di laut mengkonsumsi plastik karena kesalahan. Itu disebabkan karena tidak jarang plastik yang terdapat di laut akan tampak sebagai makanan bagi hewan laut. Plastik tidak dapat dicerna dan akan terus berada pada organ pencernaan kewan laut ini, sehingga menyumbat saluran pencernaan dan menyebabkan kematian melalui kelaparan atau infeksi. Bahan beracun yang digunakan dalam pembuatan plastik dapat terurai dan masuk ke lingkungan ketika terkena air. Racun ini bersifat hidrofobik (berkaitan dengan air) dan menyebar di permukaan laut. Dengan demikian plastik jauh lebih mematikan di laut daripada di darat.

\section{B. Pencemaran Lingkungan Oleh Limbah Rumah Tangga Sebagai suatu Perbuatan Tindak Pidana}

UU No. 32 Tahun 2009 tentang Perlindungan dan Pengelolaan Lingkungan Hidup mengatur tentang Hak, Kewajiban dan Larangan yang berkaitan dengan perlindungan dan pengelolaan lingkungan hidup dalam Bab $X$ dari Pasal 65 sampai dengan Pasal 69. Pasal 65 dan Pasal 66 mengatur tentang Hak, Pasal 67 dan Pasal 68 mengatur tentang Kewajiban sedangkan Pasal 69 tentang Larangan. Berkaitan dengan penggolongan suatu perbuatan digolongkan sebagai perbuatan tindak pidana lingkungan hidup, disebutkan dalam Pasal 69 yang berisi tentang 'Larangan', dengan dilakukannya 'larangan' sebagaimana yang disebutkan dalam Pasal 69, maka perbuatan tersebut sudah tergolong sebagai suatu tindak pidana lingkungan hidup. Pasal 69 berbunyi sebagai berikut: ${ }^{11}$

(1). Setiap orang dilarang:

\footnotetext{
${ }^{11}$ H.M Hadin Muhjad, Op-Cit, hlm 279-280.
}

\footnotetext{
${ }^{9} \mathrm{Ibid}, \mathrm{hlm} .90$.

${ }^{10}$ Rosmidah Hasibuan, Op-Cit, hlm. 46-47.
} 
a. melakukan perbuatan yang mengakibatkan pencemaran dan/atau perusakan lingkungan hidup;

b. memasukkan B3 yang dilarang menurut peraturan perundang-undang dan ke dalam wilayah Negara Kesataun Republik Indonesia;

c. memasukkan limbah yang berasal dari luar wilayah Negara Kesatuan Republik Indonesia ke media lingkungan hidup Negara Kesatuan Republik Indonesia;

d. memasukkan limbah B3 ke dalam wilayah Negara Kesatuan Republik Indonesia;

e. membuang limbah ke media lingkungan hidup;

f. membuang B3 dan limbah B3 ke mdia lingkungan hidup;

g. melepaskan produk rekayasa genetik ke media lingkungan hidup yang bertentangan dengan peraturan perundang-undangan atau izin lingkungan;

h. melakukan permukaan lahan dengan cara membakar;

i. menyusun amdal tanpa memiliki sertifikat kompetensi penyusun amdal; dan/atau

j. memberikan informasi palsu, menyesatkan, menghilangkan informasi, merusak informasi, atau memberikan keterangan yang tidak benar

Pasal 69 jelas menyebutkan ada 18 (delapan belas) tindak pidana perlindungan dan pengelolaan lingkungan hidup yaitu: ${ }^{12}$

1. membuat perbuatan yang mengakibatkan dilampauinya baku mutu ambien, baku mutu air, baku mutu air laut, atau kriteria baku kerusakan lingkungan hidup;

2. kelalaian mengakibatkan dilampauinya baku mutu udara ambien, baku mutu air, baku mutu air laut, atau kriteria baku kerusakan lingkungan hidup;

3. melanggar baku mutu air limbah, baku mutu emisi atau baku mutu gangguan;

4. melepaskan dan/atau menedrakan produk rekayasa genetik ke media

12 Mahrus Ali dan Ayu Izza Elvany, Hukum Pidana Lingkungan; Sistem Pemidanaan Berbasis Konservasi Lingkungan Hidup UII Press, Yogyakarta, 2014, hlm. 13 28. lingkungan hidup yang bertentangan dengan peraturan perundangundangan atau izin lingkungan;

5. melakukan pengelolaan limbah B3 tanpa izin;

6. menghasilkan limbah B3 dan tidak melakukan pengelolaan;

7. melakukan dumping limbah dan/atau bahan ke media lingkungan hidup tanpa izin;

8. memasukkan limbah ke dalam wilayah Indonesia;

9. memasukkan limbah B3 ke dalam wilayah Negara Indonesia;

10. memasukkan B3 yang dilarang menurut peraturan perundang-undangan ke dalam wilayah Indonesia;

11. melakukan pembakaran lahan;

12. melakukan usaha dan/atau kegiatan tanpa memiliki izin lingkungan;

13. menyusun amdal tanpa memilki sertifikat kompetensi penyusunan amdaal;

14. menerbitkan izin lingkungan tanpa dilengkapi dengan amdal UKL-UPL;

15. tidak melakukan pengawasan terhadap ketaatan penanggungjawab usaha dan/atau kegiatan terhadap peraturan perundang-undangan dan izin lingkungan;

16. memberikan informasi palsu, menyesatkan, menghilangkan informasi, merusak informasi atau memberikan keterangan yang tidaks benar yang diperlukan dalam kaitannya dengan pengawasan dan penegakan hukum yang berkaitan dengan perlindungan dan pengelolaan lingkungan hidup;

17. tidak melaksnakan paksaan pemerintah;

18. mencegah, menghalang-halangi atau menggagalkan pelaksanaan tugas pejabat pengawas lingkungan hidup dan/atau pejabat pegawai negeri sipil.

Melihat pada pembahasan di atas tentang limbah rumah tangga dan kriteria suatu tindak pidana, maka pencemaran oleh limbah rumah tangga termasuk sebagai tindak pidana dan dari ke delapan belas jenis tindak pidana perlindungan dan pengelolaan lingkungan hidup sebagaimana disebutkan dalam Pasal 69 
di atas, maka yang termasuk sebagai tindak pidana pencemaran limbah rumah tangga adalah:

1. melakukan perbuatan yang mengakibatkan dilampauinya baku mutu ambien, baku mutu air, baku mutu air laut atau kriteria baku kerusakan lingkungan hidup;

2. kelalaian mengakibatkan dilampauinya baku mutu udara ambien, baku mutu air, baku mutu air laut atau kriteria baku kerusakan lingkungan hidup;

3. melanggar baku mutu air limbah, baku mutu emisi atau baku mutu gangguan;

4. menghasilkan limbah B3 dan tidak melakukan pengelolaan;

Pasal 1 angka 13 UU No. 32 Tahun 2009 menjelaskan bahwa baku mutu lingkungan hidup adalah ukuran batas atau kadar makhluk hidup, zat energi atau komponen yang ada ata harus ada dan/atau unsur pencemar yang ditenggang keberadaannya dalam suatu sumber daya tertentu sebagai unsur lingkungan hidup. apabila baku mutu lingkungan hidup terlampaui, maka yang terjadi adalah pencemaran lingkungan. ${ }^{13}$

Sedangkan pengertian kriteria baku kerusakan lingkungan hidup menurut Pasal 1 angka 15 adalah ukuran batas perubahan sifat fisik, kimia, dan/atau hayati lingkungan hidup yang dapat ditenggang oleh lingkungan hidup untuk dapat tetap melestarikan fungsinya. Apabila kriteria baku lingkungan hidup yang dirusak, maka yang terjadi adalah kerusakan lingkungan. ${ }^{14}$

Pasal 1 angka 21 menjelaskan bahwa Bahan Berbahaya dan Beracun yang selanjutnya disingkat B3 adalah Zat, energi, dan/atau komponen lain yang karena sifat, konsentrasi dan/atau jumlahnya, baik secara langsung maupun tidak langsung, dapat mencemarkan dan/atau merusak lingkungan hidup, dan/atau membahayakan lingkungan hidup, kesehatan, serta kelangsungan hidup manusia dan makhluk hidup. Pasal 1 angka 22 menyebutkan bahwa limbah bahan berbahaya dan beracun yang selanjutnya disebut limbah B3 adalah sisa

\footnotetext{
13 Takdir Rahmadi, Hukum Lingkungan di Indonesia, RajaGrafindo Persada, Jakarta, 2011, hlm. 90.

${ }^{14} \mathrm{lbid}, \mathrm{hlm}$. 90-91.
}

suatu usaha dan/atau kegiatan yang mengandung B3. ${ }^{15}$

Dari penjelasan Pasal 1 angka 13, 15, 21 dan 22 UU No. 32 Tahun 2009, maka pencemaran lingkungan oleh limbah rumah tangga telah memenuhi kriteria sebagai suatu tindak pidana, karena limbah rumah tangga yang merupakan sisa hasil kegiatan rumah tangga baik itu berbentuk cair maupun padat sudah melampaui ambang batas baku mutu yang disyaratkan dan merusak atau mencemarkan lingungan hidup.

\section{Sanksi Terhadap Pelaku Pencemaran Limbah Rumah Tangga Menurut UU No. 32 Tahun 2009 Tentang Perlindungan Dan Pengelolaan Lingkungan Hidup}

UU No. 32 Tahun 2009 tentang Perlindungan dan Pengelolaan Lingkungan Hidup disebutkan tentang Ketentuan Pidana terhadap pelaku pencemaran lingkungan hidup yang diatur dalam Bab XV. Untuk pelaku pencemaran limbah rumah tangga bisa dipidana dengan Pasal 98, Pasal 99, Pasal 100 dan Pasal 102 serta Pasal 103 yang berbunyi sebagai berikut:

Pasal 98 UU No. 32 Tahun 2009: ${ }^{16}$

(1). Setiap orang yang dengan sengaja melakukan perbuatan yang mengakibatkan dilampauinya baku mutu udara ambien, baku mutu air, baku mutu air laut, atau kriteria baku kerusakan lingkungan hidup, dipidana dengan pidana penjara paling singkat 3 (tiga) tahun dan paling lama 10 (sepuluh) tahun dan denda paling sedikit Rp. 3.000.000.000,00 (tiga miliar rupiah) dan paling banyak $\mathrm{Rp}$. 10.000.000.000,00 (sepuluh miliar rupiah).

(2). Apabila perbuatan sebagaimana dimaksud pada ayat (1) mengakibatkan orang luka dan/atau bahaya kesehatan manusia, dipidana dengan pidana penjara paling singkat 4 (empat) tahun dan paling lama 12 (dua belas) tahun dan denda paling sedikit Rp. 4.000.000.000,00 (empat miliar rupiah) dan paling banyak Rp. 12.000.000.000,00 (dua belas milira rupiah).

\footnotetext{
${ }^{15}$ H.M Hadin Muhjad, Op-Cit, hlm. 243-244.

${ }^{16}$ H.M Hadin Muhjad, Ibid, hlm. 293.
} 
(3). Apabila perbuatan sebagaimana dimaksud pada ayat (1) menakibatkan orang luka berat atau mati, dipidana dengan pidana penjara paling singkat 5 (lima) tahun dan paling lama 15 (lima belas) tahun dan denda paling sedikit Rp. 5.000.000.000,00 (lima miliar rupiah) dan paling banyak Rp. 15.000.000.000,00 (lima belas miliar rupiah).

Pasal 99 UU No. 32 Tahun 2009: ${ }^{17}$

(1). Setiap orang yang arena kelalaiannya mengakibatkan dilampauinya baku mutu udara ambien, baku mutu air, baku mutu air laut, atau kriteria baku kerusakan lingkungan hidup, dipidana dengan pidana penjara paling singkat 1 (satu) tahun dan paling lama 3 (tiga) tahun dan denda paling sedikit Rp. 1.000.000.000,00 (satu miliar rupiah) dan paling banyak Rp. $3.000 .000 .000,00$ (tiga miliar rupiah).

(2). Apabila perbuatan sebagaimana dimaksud pada ayat (1) mengakibatkan orang luka dan/atau bahaya kesehatan manusia, dipidana dengan pidana penjara paling singkat 2 (dua) tahun dan paling lama 6 (enam) tahun dan denda paling sedikit Rp. 2.000.000.000,00 (dua miliar rupiah) dan paling banyak Rp. $6.000 .000 .000,00$ (enam miliar rupiah).

(3). Apabila perbuatan sebagaimana dimaksud pada ayat (1) mengakibatkan orang luka berat atau mati, dipidana dengan pidana penjara paling singkat 3 (tiga) tahun dan paling lama 9 (sembilan) tahun dan pidana denda paling sedikit Rp. 3.000.000.000,00 (tiga miliar rupiah) dan paling banyak Rp. 9.000.000.000,00 (sembilan miliar rupiah).

Pasal 100 UU No. 32 Tahun 2009: ${ }^{18}$

(1). Setiap orang yang melanggar baku mutu air limbah, baku mutu emisi, atau baku mutu gangguan dipidan dengan pidana penjara paling lama 3 (tahun) dan denda paling

${ }^{17} \mathrm{Ibid}, \mathrm{hlm} .294$.

${ }^{18} \mathrm{lbid}, \mathrm{hlm} .294-295$. banyak Rp. 3.000.000.000,00 (tiga miliar rupiah).

(2). Tindak pidana sebagimana dimaksud pada ayat (1) hanya dapat dikenakan apabila sanksi administratif yang telah dijatuhkan tidak dipatuhi atau pelanggaran dilakukan lebih dari satu kali.

Pasal 102 UU No. 32 Tahun 2009: ${ }^{19}$

Setiap orang yang melakukan pengelolaan limbah B3 tanpa izin sebagaimana dimaksud dalam Pasal 59 ayat (4), dipidana dengan pidana penjara paling singkat 1 (satu) tahun dan paling lama 3 (tiga) tahun dan denda paling sedikit Rp. 1.000.000.000,00 (satu miliar rupaih) dan paling banyak Rp. $3.000 .000 .000,00$ (tiga miliar rupiah).

Pasal 103 UU No. 32 Tahun 2009::

Setiap orang yang menghasilkan limbah B3 dan tidak melakukan pengelolaan sebagaimana dimaksud dalam Pasal 59, dipidana dengan pidana penjara paling singkat 1 (satau) tahun dan paling lama 3 (tiga) tahun dan denda paling sedikit Rp. 1.000.000.000,00 (satu miliar rupiah) dan paling banyak Rp. $3.000 .000 .000,00$ (tiga miliar rupiah).

Pasal-pasal di atas tidak secara jelas menyebutkan bahwa pelaku pencemaran limbah rumah tangga akan dipidana sebagaimana dalam pasal-pasal Ketentuan Pidana, tetapi pasal-pasal yang ada menyebutkan pelaku pencemaran lingkungan hidup secara general/umum, dimana tercakup didalamnya pelaku pencemaran limbah rumah tangga.

\section{PENUTUP}

\section{A. Kesimpulan}

1. Limbah rumah tangga dapat mengganggu kesehatan manusia dan kelangsungan hidup makhluk hidup lainnya. Menumpuknya limbah rumah tangga mengandung bakteri dan sangat membahayakan kesehatan lingkungan. Dampak dari limbah rumah tangga sangatlah mengganggu lingkungan hidup karena mengancam kehidupan ekosistem air, menyebabkan penyakit, menurunnya kualitas air, tumbuhnya kuman penyakit,

\footnotetext{
${ }^{19} \mathrm{Ibid}, \mathrm{hlm} .295$.

${ }^{20}$ Ibid.
} 
membuat air tak layak untuk di konsumsi dan menyebabkan banjir.

2. Pencemaran lingkungan oleh limbah rumah tangga telah memenuhi kriteria sebagai suatu tindak pidana, karena limbah rumah tangga yang merupakan sisa hasil kegiatan rumah tangga baik itu berbentuk cair maupun padat sudah melampaui ambang batas baku mutu yang disyaratkan dan merusak atau mencemarkan lingkungan hidup.

3. Sanksi bagi pelaku pencemaran limbah rumah tangga menurut UU No. 32 Tahun 2009 adalah dikenakan pidana penjara paling singkat 1 (satu) tahun dan paling lama 15 (lima belas) tahun dan denda paling sedikit Rp. 1.000.000.000,00 (satu miliar rupiah) dan paling banyak Rp. 15.000.000.000,00 (lima belas miliar rupiah) sebagaimana tercantum dalam Pasal 98, 99, 100, 102 dan 103. Terdapat akumulasi pidana pokok yaitu pidana penjara dan pidana denda.

\section{B. Saran}

Adapun saran yang dapat diberikan terhadap pembahasan skripsi ini adalah sebagai berikut:

1. Perlu adanya sosialisasi kepada masyarakat tentang Limbah Rumah Tangga, baik Peraturan Perundangundangannya maupun Sanksi Hukum yang terkait. Agar masyarakat lebih memperhatikan akan dampak dari limbah rumah tangga terhadap lingkungan sekitar dan kesehatan masyarakat.

2. Perlu adanya pembuatan lubang penampungan dan drainase dari pemerintah setempat, sebagai upaya penanggulangan pembuangan limbah. Agar masyarakat tidak lagi membuang limbah rumah tangga dengan sembarangan.

3. Perlu adanya ketegasan hukum bagi setiap pelaku pencemaran berdasarkan UU No.32 Tahun 2009 tentang Perlindungan dan Pengelolaan Lingkungan Hidup, Karena pencemaran lingkungan hidup oleh limbah rumah tangga sangatlah membahayakan kesehatan manusia dan merusak lingkungan hidup sekitar. Oleh karena itu penerapan pasal-pasal tentang Ketentuan Pidana dalam UU No.32 tahun 2009 harus dilaksanakan.

\section{DAFTAR PUSTAKA}

Sumber buku:

Abdurrahman, Pengantar Hukum Lingkungan, cetakan Kedua, Alumni, Bandung

Ali Mahrus dan Ayu Izza Elvany, Hukum Pidana Lingkungan; Sistem Pemidanaan Berbasis Konservasi Lingkungan Hidup UII Press, Yogyakarta, 2014

Ali Mahrus, Asas-Asas Hukum Pidana Korporasi, RajaGrafindo Perkasa, Jakarta, 2013

Cahyadi Antonius dan E. Fernando $M$ Manullang, Pengantar Ke Filsafat Hukum, Kencana Prenada Media Gorup, Jakarta, 2007

Hasibuan Rosmidah, Analisis Dampak Limbah/Sampah Rumah Tangga Terhadap Pencemaran Ligkungan Hidup, diakses dari Jurnal IImiah "Advokasi" vol 04 No. 01 Maret 2016 pada tanggal 27 Maret 2020.

Kahan Dan M dalam Mahrus Ali dan Ayu Izza Elvany, Hukum Pidana Lingkungan,; Sistem Pemidanaan Berbasis Konservasi Lingkungan Hidup, UII Press, Yogyakarta, 2014

Kamus Besar Bahasa Indonesia, Balai Pustaka, Jakarta, 1997

Luna Erik dalam dalam Mahrus Ali dan Ayu Izza Elvany, Hukum Pidana

Lingkungan,; Sistem Pemidanaan Berbasis Konservasi Lingkungan Hidup, UII Press, Yogyakarta, 2014

Luthan Salman, dalam Mahrus Ali dan Ayu Izza Elvany, Hukum Pidana Lingkungan,; Sistem Pemidanaan Berbasis Konservasi Lingkungan Hidup, UII Press, Yogyakarta, 2014

Maramis Frans, Hukum Pidana Umum dan Tertulis di Indonesia, Rajwali Pers, Jakarta, 2013

Moeljatno, Azas-Azas Hukum Pidana, Bina Aksara, Jakarta, 1983

Muladi dan Barda Nawawi Arief, Teori dan Kebijakan Pidana, cet. Kedua, Alumni, Bandung, 1992 
Muhjad H.M. Hadin, Hukum Lingkungan Sebuah Pengantar Untuk Konteks Indonesia, Genta Publishing, Yogyakarta, 2015

Prodjodikoro Wirjono, Asas-asas Hukum Pidana di Indonesia, edisi ketiga, Refika Aditama, Bandung, 2003

Poernomo Bambang, Azas-Azas Hukum Pidana, Ghalia Indonesia, Jakarta, cet. ke-3, 1978

Rahmadi Takdir, Hukum Lingkungan di Indonesia, RajaGrafindo Persada, Jakarta, 2011

Ramli Samsul dan Fahrurazi, Bacaan Wajib Swakelola Pengadaan Barang/Jasa, Vismedia Pustaka, Jakarta, 2014

Salim Emil, Lingkungan Hidup dan Pembangunan, Mutiara Sumber Widya, Jakarta

Sianturi S.R, Azas-Azas Hukum Pidana di Indonesia dan Penerapannya, Alumni AHM-PTHM, Jakarta, 1989

Simorangkir J.C.T, Rudy T Erwin dan A.T Prasetyo, Pengertian Sanksi, 2000,

Siahaan N.H.T, Hukum Lingkungan Dan Ekologi Pembangunan, Erlangga, Jakarta, 2004

Soerjono Soekanto dan Sri Mamudji, Penelitian Hukum Normatif; Suatu Tinjauan Singkat, PT Raja Grafindo Persada, Jakarta, 2003

Soemartono R.M Gatot P, Hukum Lingkungan Indonesia, Sinar Grafika, Jakarta

Soesilo R, KUHP Serta Komentar-Komentarnya Lengkap Pasal Demi Pasal, Politea, Bandung, 1996

UU No. 32 Tahun 2009 Tentang Perlindungan Dan Pengelolaan Lingkungan Hidup Peraturan Menteri Lingkungan Hidup Dan Kehutanan Republik Indonesia Lampiran II Nomor P.68/Menlhk/Setjen/Kum.1/8/2016 tentang Baku Mutu Air Limbah Domestik

Sumber Internet:

Jenis Sampah- Pengertian, Sumber, Prinsip, Pengolahan, Faktor, Dampak, diakses dari https://www.gurupendidikan.co.id pada tanggal 27 Maret 2020.

Khan Titi Chadar, Dampak Limbah Rumah Tangga dan Penanggulangannya, diakses dari tiyfaoji.blogspot.com pada tanggal 1 April 2020.
Limbah, diakses dari https://id.m.wikipedia.org pada tanggal 30 Maret 2020

Pencemaran Menurut SK Menteri Kependudukan Lingkungan Hidup No. 02/MENKLH/1988, diakses dari https://id.m.wikipedia.org pada tanggal 28 Maret 2020.

Pencemaran, diakses dari https://brainly.co.id pada tanggal 28 Maret 2020. Pencemaran air, diakses dari https://id.m.wikipedia.org pada tanggal 28 Maret 2020.

Pencemaran udara, diakses dari https://lingkungan hidup.co pada tanggal 28 Maret 2020.

Pencemaran Tanah, diakses dari https://www.kompas .com pada tanggal 28 Maret 2020.

Pencemaran Logam berat, diakses dari www.saka.co.id pada tanggal 28 Maret 2020.

Pencemaran suara, diakses dari https://ilmugeografi.com pada tanggal 28 Maret 2020.

Pengertian Limbah, diakses dari https://www. romadecade.org pada tanggal 30 Maret 2020.

Pengertian Limbah: Jenis-jenis, Dampak dan Contoh Limbah, diakses dari https:// salamadian.com pada tanggal 30 Maret 2020

Pengaruh Limbah Rumah Tangga Bagi Lingkungan, diakses dari https://bandungkab.go.id pada tanggal 1 April 2020.

Pengertian Sanksi, diakses dari www.pengertian menurut para ahli.com pada tanggal 1 April 2020.

Pengertian Sanksi, diakses dari telingasemut.blogspot.co.id pada tanggal 1 April 2020. 